\title{
Flexibility in otherwise consistent non-breeding movements of a long-distance migratory seabird, the long-tailed skua
}

\author{
Rob van Bemmelen ${ }^{1,2, *}$, Børge Moe $^{3}$, Sveinn Are Hanssen ${ }^{4}$, Niels Martin Schmidt ${ }^{5,6}$, \\ Jannik Hansen ${ }^{5}$, Johannes Lang ${ }^{7,8}$, Benoît Sittler ${ }^{7,9}$, Loïc Bollache ${ }^{7,10,11}$, Ingrid Tulp ${ }^{1}$, \\ Raymond Klaassen ${ }^{12}$, Olivier Gilg ${ }^{7,13}$
}

\author{
${ }^{1}$ Wageningen Marine Research, 1970 AB, IJmuiden, The Netherlands \\ ${ }^{2}$ Resource Ecology Group, Wageningen University \& Research, 6708 PB, Wageningen, The Netherlands \\ ${ }^{3}$ Norwegian Institute for Nature Research, 7034 Trondheim, Norway \\ ${ }^{4}$ Norwegian Institute for Nature Research, FRAM - High North Research Centre for Climate and the Environment, \\ 9007 Tromsø, Norway \\ ${ }^{5}$ Department of Bioscience, Aarhus University, 4000 Roskilde, Denmark \\ ${ }^{6}$ Arctic Research Centre, Aarhus University, 8000 Aarhus C, Denmark \\ ${ }^{7}$ Groupe de Recherche en Ecologie Arctique, 21440 Francheville, France \\ ${ }^{8}$ Working Group for Wildlife Biology, Justus Liebig University Giessen, 35392 Giessen, Germany \\ ${ }^{9}$ Chair for Nature Protection and Landscape Ecology, University of Freiburg, 79106 Freiburg, Germany \\ ${ }^{10}$ Laboratoire Chrono-environnement, 25000 Besançon, France \\ ${ }^{11}$ Université de Bourgogne France Comté, 21000 Dijon Cedex, France \\ ${ }^{12}$ Dutch Montagu's Harrier Foundation and Conservation Ecology Group, \\ Groningen Institute for Evolutionary Life Sciences (GELIFES), University of Groningen, 9700 CC, Groningen, The Netherlands \\ ${ }^{13}$ Laboratoire Biogéosciences, UMR CNRS 6282, Université de Bourgogne, Dijon, France
}

\begin{abstract}
Quantifying within- and between-individual variation in animal migration strategies is a first step towards our understanding of the ability of migrants to adjust to changes in the environment. We studied consistency (or, conversely, flexibility) in movement patterns at large $(>1000 \mathrm{~km})$ to meso-scales $(100-1000 \mathrm{~km})$ during the non-breeding season of the long-tailed skua Stercorarius longicaudus, a long-distance migratory Arctic seabird, using light-based geolocation. We obtained 97 annual tracks of 38 individuals and quantified similarity between routes. Overall, tracks of the same individual were generally within about 200 to $300 \mathrm{~km}$ of their previous year's route, and more similar than tracks of different individuals. Some flexibility was observed during migration, but individuals were faithful to their staging areas in the North Atlantic and in the Benguela Current off Namibia and South Africa. Over the course of the winter, an increasing number of individuals started to deviate - up to $5200 \mathrm{~km}$ - from the previous year's route. Intriguingly, individuals could be highly consistent between 2 consecutive years and flexible between other years. Site-shifts in late winter seem to reflect responses to local conditions, but what promotes this larger flexibility remains unclear and requires further study. Our results show that individual long-tailed skuas are generally consistent in their itineraries, but can show considerable flexibility in some years. The flexibility in itineraries suggests that long-tailed skuas are able to adjust to environmental change, but the mechanisms leading to the observed within- and between-individual variation in movement patterns are still poorly understood.
\end{abstract}

KEY WORDS: Individual consistency - Repeatability · Stercorarius longicaudus - Seabirds · Tracking $\cdot$ Non-breeding movements $\cdot$ Flexibility

${ }^{*}$ Corresponding author: rvanbemmelen@gmail.com

${ }^{\S}$ Advance View was available online February 15, 2017
(0) The authors 2017. Open Access under Creative Commons by Attribution Licence. Use, distribution and reproduction are unrestricted. Authors and original publication must be credited. 


\section{INTRODUCTION}

The ability to track the movements of individual birds throughout multiple annual cycles has fuelled interest in individual variation in migration and wintering patterns (e.g. Phillips et al. 2005, Dias et al. 2011, Guilford et al. 2011, Vardanis et al. 2011). Quantifying variation in movement patterns within and between individuals is a first step to ultimately understand the ability of populations to adjust their movement patterns to changes in the environment, as selection acts on phenotypic variation (Alerstam 2006, van Noordwijk et al. 2006).

Intriguingly, species vary in the degree of individual consistency (or, conversely, their flexibility) in movement patterns, i.e., the degree to which individuals use the same migration routes or staging areas between years (Dias et al. 2011, Guilford et al. 2011, McFarlane Tranquilla et al. 2014, Vardanis et al. 2016). We are only starting to understand what drives consistency in individual use of staging areas, but it is generally assumed that the spatio-temporal predictability of resources is important (Newton 2010, Trierweiler et al. 2013). Seabirds are an interesting species group in this respect, as oceanic areas show large spatio-temporal differences in both availability and predictability of resources (Longhurst 2006, Weimerskirch 2007). While seabirds likely target areas with high productivity for foraging (which can vary in predictability; Weimerskirch 2007), migration routes connecting staging areas are often strongly linked to wind patterns that allow efficient travelling (Felicísimo et al. 2008), and they often traverse large areas with low availability and/or predictability of resources. Thus, movement patterns of seabirds during the non-breeding season might consist of a combination of consistent itineraries in periods or areas with high resource availability and more flexible, nomadic movement patterns in periods or areas with low resource availability, such as areas crossed during migration. A synthesis on how consistency in staging site and migration routes use might vary throughout the non-breeding season is still lacking.

Using light-based geolocation to track individuals, we studied the consistency of movement patterns of the long-tailed skua Stercorarius longicaudus during the non-breeding season at large $(>1000 \mathrm{~km})$ to meso (100-1000 km) scales. This long-distance migratory seabird breeds in the sub- to high Arctic. Details of migration routes, stopovers and movements during winter in the southern Atlantic have only recently been revealed (Sittler et al. 2011, Gilg et al. 2013). Gilg et al. (2013) showed that long-tailed skuas have a strategy of itinerancy, i.e. visiting multiple places throughout the winter (Moreau 1972). This behaviour is not uncommon among seabirds (e.g. Phillips et al. 2005, Hedd et al. 2012, Fijn et al. 2013, van der Winden et al. 2014, Orben et al. 2015) but notably different from a strategy of residency where only a single wintering site is used (McFarlane Tranquilla et al. 2014, Yamamoto et al. 2014). Itinerancy is an interesting strategy in the context of consistency versus flexibility in site use, as it, at least intuitively, leaves more possibility for flexibility, even during the winter period.

We quantified variation in individual movement patterns throughout the entire non-breeding season, thus including migration and winter periods. In particular, we investigated if, where and when movement patterns differ between and within individuals. As long-tailed skuas seem to exploit areas with predictable high productivity, e.g. the Benguela Current and the central North Atlantic (Gilg et al. 2013), we expected individuals to revisit the same staging areas and thus to exhibit high levels of consistency in their itineraries.

Most earlier studies on the consistency of bird migration were based on individuals tracked over 2 consecutive years (e.g. Dias et al. 2011, Guilford et al. 2011, McFarlane Tranquilla et al. 2014). Although this allows partitioning of within- and between-individual variation in behaviour, 3 or more years of tracking data are needed to study whether individuals vary in their behavioural flexibility (i.e. not the level, but the 'width' of their behavioural response; Dingemanse \& Wolf 2013). This idea has, to our best knowledge, not been explored to date, but is needed to understand if and how migrants may cope with environmental change. We tracked individual long-tailed skuas for 3 or more years and investigated whether individual birds display the same level of consistency or flexibility across years, or can be consistent between some years but flexible between other years.

\section{MATERIALS AND METHODS}

\section{Study species, study areas, capture techniques and geolocator deployment}

Two subspecies are recognized in the long-tailed skua: the nominate subspecies Stercorarius longicaudus longicaudus breeds from Scandinavia eastwards and is replaced by the white-bellied subspecies $S . l$. pallescens from eastern Siberia to Svalbard (Manning 1964). Only the migration of S. 1. pallescens has been revealed before, by Gilg et al. (2013), showing 
that skuas breeding in Greenland and Svalbard depart from the breeding areas in late August, migrate via a stopover in the central North Atlantic towards West Africa and arrive at the main wintering grounds off southern Africa between late September and late November. Spring migration commences in March or April, and birds arrive on the breeding grounds in late May/early June.

Adult long-tailed skuas of the nominate subspecies S. 1. longicaudus were captured between 2011 and 2015 in the Vindelfjällen Nature Reserve near Ammarnäs, Sweden $\left(65^{\circ} 59^{\prime} \mathrm{N}, 16^{\circ} 01^{\prime} \mathrm{E}\right)$. Adults of the Nearctic subspecies $S$. 1. pallescens were captured between 2010 and 2015 at Kongsfjorden, Svalbard $\left(79^{\circ} 57^{\prime} \mathrm{N}, 12^{\circ} 6^{\prime} \mathrm{E}\right.$ ) and 3 sites in Greenland: Zackenberg $\left(74^{\circ} 28^{\prime} \mathrm{N}, 20^{\circ} 34^{\prime} \mathrm{W}\right)$, Karupelv ( $72^{\circ} 50^{\prime} \mathrm{N}, 24^{\circ} 00^{\prime} \mathrm{W}$ ) and Hochstetter Forland $\left(75^{\circ} 09^{\prime} \mathrm{N}, 19^{\circ} 40^{\prime} \mathrm{W}\right)$. Birds were captured on the nest using bow nets or remotetriggered nooses and away from the nest using handheld net guns or noose carpets (in a few cases, birds were lured by a decoy and playback of the 'long call' - a call used in courtship and territorial disputes). Geolocators of 3 types (Mk-18L and Mk-18H, produced by the British Antarctic Survey, and C65, produced by Migrate Technology) were leg-mounted using a Darvic ring. The total added weight (geolocator, Darvic ring, cable tie, self-amalgamating tape and super glue) amounted to ca. 2.2, 2.6 and $1.8 \mathrm{~g}$ for the Mk-18L, Mk-18H and C65 types, respectively, which is 0.5 to $1.2 \%$ of the mean body mass of adult longtailed skuas ( $\mathrm{n}=129$ ). In addition, biometry and a blood sample for DNA sexing were taken. Individuals were sexed using molecular techniques (Fridolfsson \& Ellegren 1999). Single tracks from 8 individuals from Greenland and Svalbard have been published earlier (Gilg et al. 2013). The period between 2 subsequent breeding seasons is referred to as a year; the data obtained in this period are referred to as a track. References to seasons are from a northern hemisphere perspective.

\section{Geolocator data analyses}

After recapture of the tagged birds, geolocators were removed and data were downloaded from the geolocators and decompressed using BASTrak (British Antarctic Survey) or IntigeoIF software (Migrate Technology). The subsequent analysis was carried out entirely using R 3.1.2 (R Core Team 2015) and a set of packages, in particular the R package 'GeoLight' (Lisovski \& Hahn 2012). Geolocators recorded ambient light level in arbitrary units (Mk-18L, Mk-18H) or lux
(C65) in 1 min intervals and saved the maximum of these values every $5 \mathrm{~min}$. Sun events were calculated unsupervised from light measurements using the function 'twilightCalc' and a light threshold value of 10 (Mk-18H) or 2 (C65). Spending the non-breeding season entirely at open sea, light measurement data from the long-tailed skuas was generally 'clean', i.e. most sun events could automatically be assigned with a relatively low amount of misclassification (due to e.g. shading events). This was checked by visual inspection of plots of date against time of sunrise or sunset, from which unlikely twilight events were identified and removed. For a sequence of potential sun angles, locations were calculated for each noon and midnight. We selected the sun angle resulting in a good fit of location estimates to the shape of the continents and a close match in latitude estimates before and after the equinoxes. Final sun angles for individual loggers ranged from $-1^{\circ}$ to $-3^{\circ}$ for the $\mathrm{Mk}-18 \mathrm{H}$ model and $-4.5^{\circ}$ to $-6.0^{\circ}$ for the $\mathrm{C} 65$ model. Position estimates from light-based geolocation typically have a mean error of $\pm 185 \mathrm{~km}$ for flying seabirds (Phillips et al. 2004) and these errors are especially large in close proximity to the equinoxes. Therefore, positions within $14 \mathrm{~d}$ from either side of the equinoxes (20 March and 22 September) were removed. Remaining positions were smoothed by calculating the $3 \mathrm{~d}$ running mean, using equations from Gilg et al. (2013). All further analyses were based on smoothed positions, with no data around the equinoxes.

\section{Staging areas}

We followed Gilg et al. (2013) in defining staging periods when distance between smoothed positions were smaller than $200 \mathrm{~km}$ for at least 3 consecutive days. Subsequently, staging areas were identified by creating a $95 \%$ utilization distribution kernel based on staging positions of all individuals, using the 'adehabitatHR' package for R (Calenge 2011). For this, a Lambert azimuthal equal-area projection was used with a grid cell size of $50 \mathrm{~km}$ and a smoothing factor of $200 \mathrm{~km}$. Kernels were estimated for 4 space/time segments of the data: (1) before 1 January, between $25^{\circ}$ and $60^{\circ} \mathrm{N}$, (2) before 1 January, south of $25^{\circ} \mathrm{N}$, (3) after 31 December, south of $25^{\circ} \mathrm{N}$ and (4) after $31 \mathrm{De}$ cember, between $25^{\circ}$ and $60^{\circ} \mathrm{N}$. The split at 1 January is well after arrival at the main wintering areas but before long-distance northward movements (Gilg et al. 2013). The area between $25^{\circ}$ and $60^{\circ} \mathrm{N}$ encompasses the large stopover area in the North Atlantic used by many seabirds, including long-tailed skuas (Sittler et 
al. 2011, Gilg et al. 2013). Few positions were obtained north of $60^{\circ} \mathrm{N}$, in particular for birds breeding at Svalbard or Greenland as they travelled here at times with more or less constant daylight. The area south of $25^{\circ} \mathrm{N}$ contains all wintering areas.

\section{Consistency in movement patterns}

Within- and between-individual consistency was mapped over entire recorded tracks, applying the method used by Guilford et al. (2011) and Dias et al. (2013) to calculate distances between tracks, based on nearest-neighbour analysis. For each position estimate in a focal track, we calculated the great-circle distance to the nearest position estimate in another track. The nearest neighbour was selected from the comparison track within a time window. Using a short time window will retain effects of different timing (hence can be used to test for route and timing consistency, which is not the topic of the current contribution), whereas a longer time window removes the effect of timing (thus tests for route consistency only). We quantified median within-individual intertrack distances for a range of time windows ( 7 to $121 \mathrm{~d}$, with steps of $6 \mathrm{~d}$ ) to investigate when the gradual removal of a timing effect on the intertrack distance fades. Next, one time window was selected visually Fig. A1 in the Appendix) and used for the analysis and figures of route consistency. If 2 tracks follow the same route, intertrack distances from the first track will be biased in the part where the comparison track has missing values due to the equinox. Therefore, if the nearest neighbour of the comparison track is a first or last position on either side of the equinox, this measurement is excluded. In this way, only more or less parallel parts of the tracks are compared, reducing bias due to missing positions during equinoxes. For reasons of interpretability, we only included comparisons of each track with tracks from the previous year.

We studied the resulting intertrack distances in 2 ways. First, we calculated the overall median intertrack distance per comparison to get an overall measure of track similarity. To allow for greater spatiotemporal resolution and inference of fidelity to staging areas, we also calculated the median intertrack distance per comparison for 6 'segments'. Median intertrack distances were then calculated within the 4 staging kernels mentioned above. In addition, median intertrack distance was calculated for the southbound (before 1 January) and northbound migration (at or after 1 January) based on all locations that fell outside the staging kernels and south of $50^{\circ} \mathrm{N}$. The resulting values were continuous, nonnegative and right-skewed. Although such data can be modelled using e.g. gamma or inverse-Gaussian error distributions, we log-transformed the data (a variance-stabilizing transformation) to allow the use of a Gaussian error distribution, for which routines to calculate intra-class correlation coefficients (ICCs or r, repeatability) are readily available (Nakagawa \& Schielzeth 2010). Bayesian generalized linear mixed models (GLMMs) were fitted using the package MCMCglmm for R (Hadfield 2010), with 130000 iterations, a burn-in of 30000 iterations and a thinning rate of 100. As an indication of significance, we provide $\mathrm{p}_{\mathrm{MCMC}}$ values, which are twice the probability that the parameter value is above or below zero. A focal individual in each comparison was included as a random effect to account for pseudo-replication and to assess within- and between-individual variance components. If populations differ in migration routes and destinations, they may inflate between-individual intertrack distances. We therefore first explored whether between-individual and within-individual intertrack distances differed between subspecies, then compared within-individual intertrack distances with between-individual intertrack distances of each subspecies.

Second, in order to more precisely illustrate spatiotemporal patterns in within- and between-individual route consistency, we bootstrapped the median of intertrack distances 10000 times for each calendar day and, separately, in each $5^{\circ}$ latitude $\times 5^{\circ}$ longitude grid cell, with only 1 track ind. ${ }^{-1}$ selected in each iteration. We performed this bootstrapping procedure for within-individual and between-individual intertrack distances. To illustrate how the spatial pattern in intertrack distances relates to staging areas, we overlaid it with the staging area kernels (see above). With median intertrack distances visualized on a continuous scale, we aided the eye by using a red outline for grid cells with a median intertrack distance of $<500 \mathrm{~km}$.

\section{Individual variation in route flexibility}

To test whether individuals differ between consecutive years in their route flexibility, e.g. whether some individuals are repeatedly flexible and others are repeatedly consistent in their routes or whether individuals may be consistent between some years and flexible between others, we calculated ICCs for within-individual median intertrack distances be- 
tween tracks from subsequent years (i.e. with only 1 yr difference) using the 'rpt.mcmcLMM' function from the 'rptR' package (Schielzeth \& Nakagawa 2013). Note that the term 'repeatability' is used here only to refer to ICC values.

\section{RESULTS}

\section{Sample size}

In Ammarnäs, Sweden, out of 46 geolocators deployed in 2011 to 2014, 27 (59\%) were retrieved by 2015. Numbers of retrievals and deployments are 20 out of $30(67 \%)$ for Svalbard, 5 out of 14 (36\%) for Zackenberg, 2 out of 6 (33\%) for Karupelv and 1 out of $3(33 \%)$ for Hochstetter Forland. Note that some individuals were refitted and recaptured multiple times and that recapturing birds in Sweden and Greenland is hampered by non-breeding years. In total, 97 tracks were obtained from 38 individual long-tailed skuas, of which 24 individuals were tracked over a period of 2 to 5 yr. See Table 1 for further specification of samples relative to subspecies. Due to logger failure or empty batteries, 14 tracks stopped prematurely between 28 December and 1 May; these were included in the analysis.

\section{General movement patterns}

All tracks are illustrated in Fig. 1 and in an animation in the Supplement at www.int-res.com/articles/ suppl/m578p197_supp/, while some examples of individual tracks are shown in Fig. 2. No systematic differences in non-breeding movements were detected between the 2 subspecies. After departure from the breeding areas, skuas proceeded south-west to stage

Table 1. Number of individual long-tailed skuas Stercorarius longicaudus (subspecies S. 1. longicaudus and S. 1. pallescens) tracked over different numbers of years

\begin{tabular}{|lccr|}
\hline No. of years & $\begin{array}{c}\text { S. } l . \\
\text { longicaudus }\end{array}$ & $\begin{array}{c}\text { S. } 1 . \\
\text { pallescens }\end{array}$ & Total \\
\hline 1 & 9 & 5 & 14 \\
2 & 1 & 3 & 4 \\
3 & 2 & 4 & 6 \\
4 & 11 & 2 & 13 \\
5 & 0 & 1 & 1 \\
Total (individuals) & 23 & 15 & 38 \\
Total (tracks) & 61 & 36 & 97 \\
\hline
\end{tabular}

in the central North Atlantic off Newfoundland. Subsequently, they went south in a relatively narrow corridor to the Canary Current off West Africa. From here, most birds migrated directly to the staging area in the Benguela Current off Namibia and South Africa, whereas 6 individuals (9 tracks) took a westerly loop to approach the Benguela Current from the west. A few proceeded further south-east into the Agulhas Current and the Southern Subtropical Convergence. A single individual (S. 1. longicaudus) went straight west from the Benguela to the Falkland Current in its second and fourth year of tracking (Fig. 2i). Other individuals lingered along the west side of Africa, in particular off Angola. The most northerly winterer was a (S. 1. longicaudus) wintering in the Canary Current. Northward movements commenced in January to March and occurred over a broad front, covering a large part of the Atlantic, and included stopovers of varying length off Angola, in the Gulf of Guinea and the Canary Current. After crossing the equator, virtually all birds staged in a large area in the central North Atlantic in April-May (mostly within the North Atlantic Drift Province), which they usually slowly crossed from west to east. Some birds staged for a few days west of Ireland before returning to the breeding grounds.

\section{Route consistency}

Intertrack distances showed a strong seasonal pattern when using a narrow time window for nearestneighbour selection, with large distances in autumn and late winter, and much smaller distances in early winter and spring. Broadening the time window greatly reduced intertrack distances, in particular in autumn (Fig. A1). For example, median within-individual intertrack distance at 15 August was ca. $3000 \mathrm{~km}$ for a time window of $7 \mathrm{~d}$, ca. $2000 \mathrm{~km}$ for a time window of $30 \mathrm{~d}$ and ca. $800 \mathrm{~km}$ for a time window of $61 \mathrm{~d}$ (Fig. A1). This was mainly caused by the fact that Swedish birds during non-breeding years had earlier autumn migration schedules, but not different migration routes. As the effect of differential timing was largely removed at a time window of $61 \mathrm{~d}$, intertrack distances obtained using this time window were therefore used in subsequent analyses.

Daily median intertrack distances were smaller within individuals than between individuals during almost the entire year (Fig. 3). Between-individual intertrack distances differed between the subspecies, and therefore 'subspecies' was included as a factor in the models. Note that this does not necessarily indi- 


\section{S. I. longicaudus}
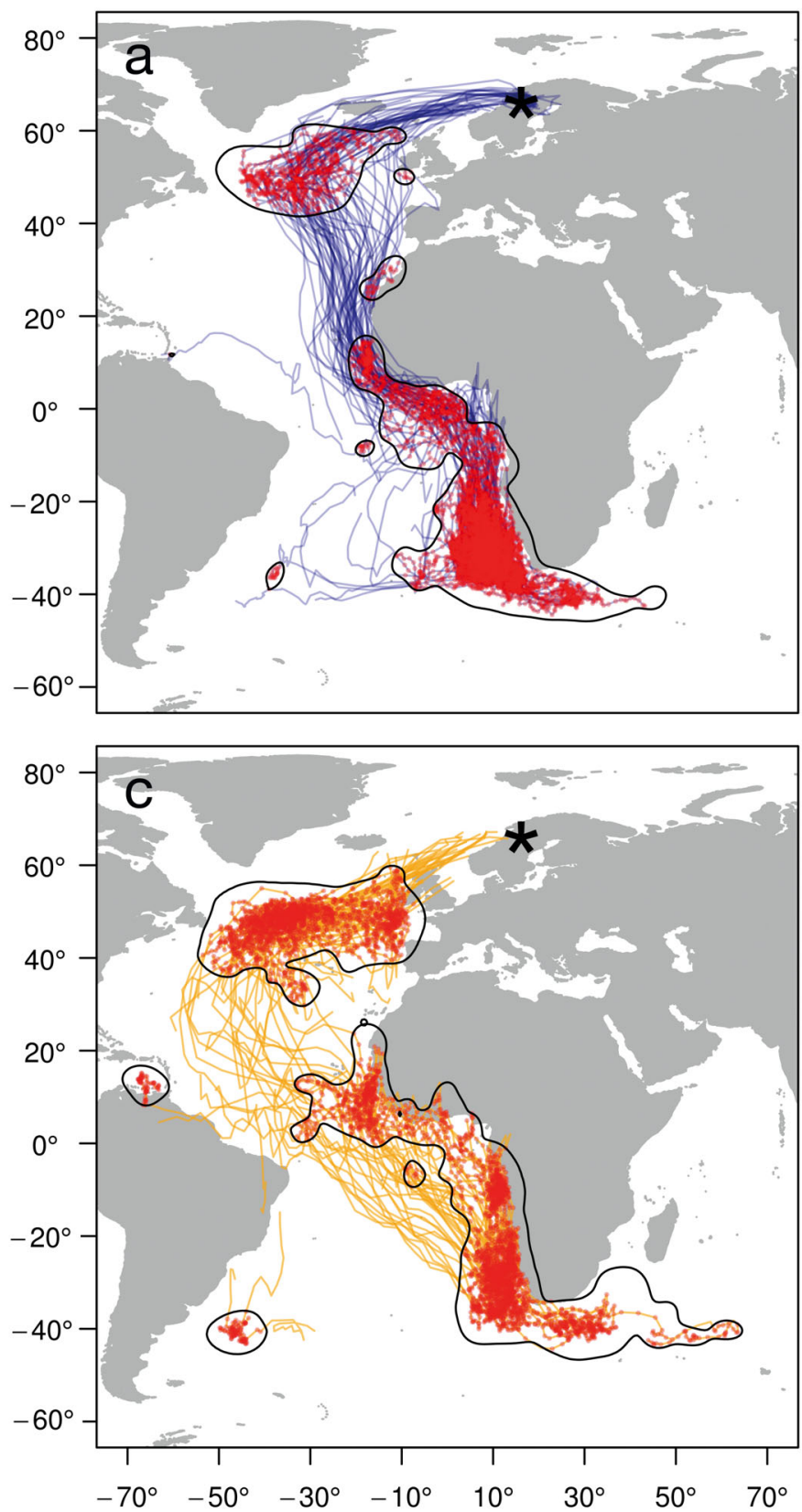

S. I. pallescens
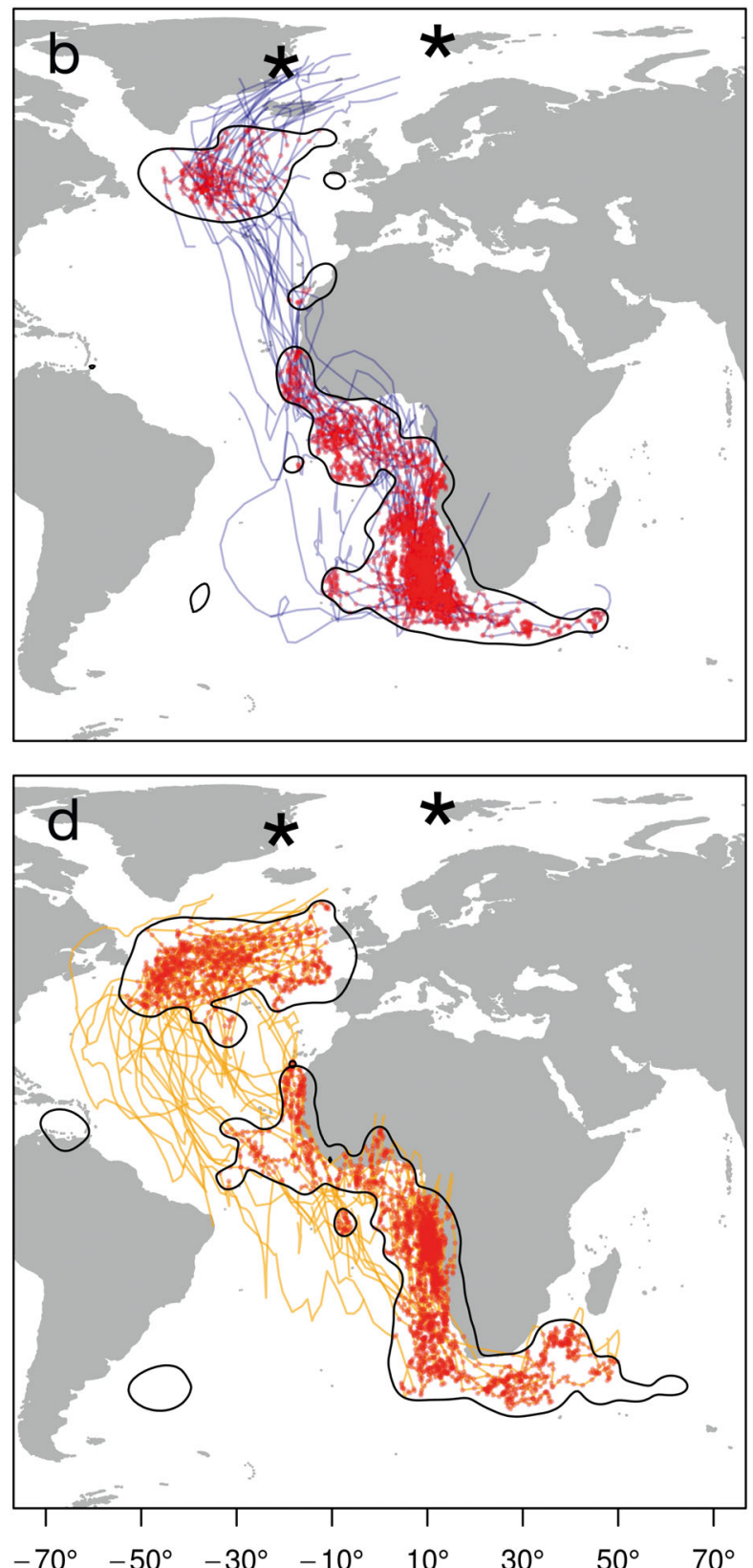

Fig. 1. Movements of the 2 subspecies of long-tailed skuas Stercorarius longicaudus, (a,c) S. l. longicaudus and (b,d) S. 1 . pallescens, in $(\mathrm{a}, \mathrm{b})$ July-December and $(\mathrm{c}, \mathrm{d})$ January-June. Red dots indicate staging periods (3 or more consecutive days with $<200 \mathrm{~km}$ between daily positions). Black stars indicate the sampled breeding sites for each subspecies. The black outlined polygons indicate $95 \%$ utilization distribution kernels for staging positions of all birds combined. Inaccuracy of geolocator position estimates is generally $\pm 185 \mathrm{~km}$, but is typically larger close to the equinoxes (Phillips et al. 2004)

cate different routes and site use between the subspecies - it only reflects a difference in the spread in routes and site use (cf. Fig. 1). Overall median intertrack distances were significantly smaller within (model-based, back-transformed posterior mean $[\mu]$ and $95 \%$ credible intervals [CI]: $\mu=274 \mathrm{~km}, 95 \% \mathrm{CI}=$ $\left.217-351 \mathrm{~km}, \mathrm{p}_{\mathrm{MCMC}}<0.001\right)$ than between individuals (Fig. 4 ; S. 1. longicaudus: $\mu=535 \mathrm{~km}, 95 \% \mathrm{CI}=347-$
$835 \mathrm{~km}, \mathrm{p}_{\mathrm{MCMC}}<0.001$, S. 1 . pallescens: $\mu=928 \mathrm{~km}$, $95 \% \mathrm{CI}=569-1484 \mathrm{~km}, \mathrm{p}_{\mathrm{MCMC}}<0.001$ ). This was also true in a model testing the median intertrack distance per segment (Fig. 4; all $\mathrm{p}_{\mathrm{MCMC}}<0.001$ ), except for the North Atlantic staging area during southbound migration (for S. 1. pallescens only; $\mathrm{p}_{\mathrm{MCMC}}=0.370$ ) and northbound migration (for both $S$. 1. longicaudus: $\mathrm{p}_{\mathrm{MCMC}}=0.536$, and S. 1. pallescens: $\mathrm{p}_{\mathrm{MCMC}}=0.020$ ). 

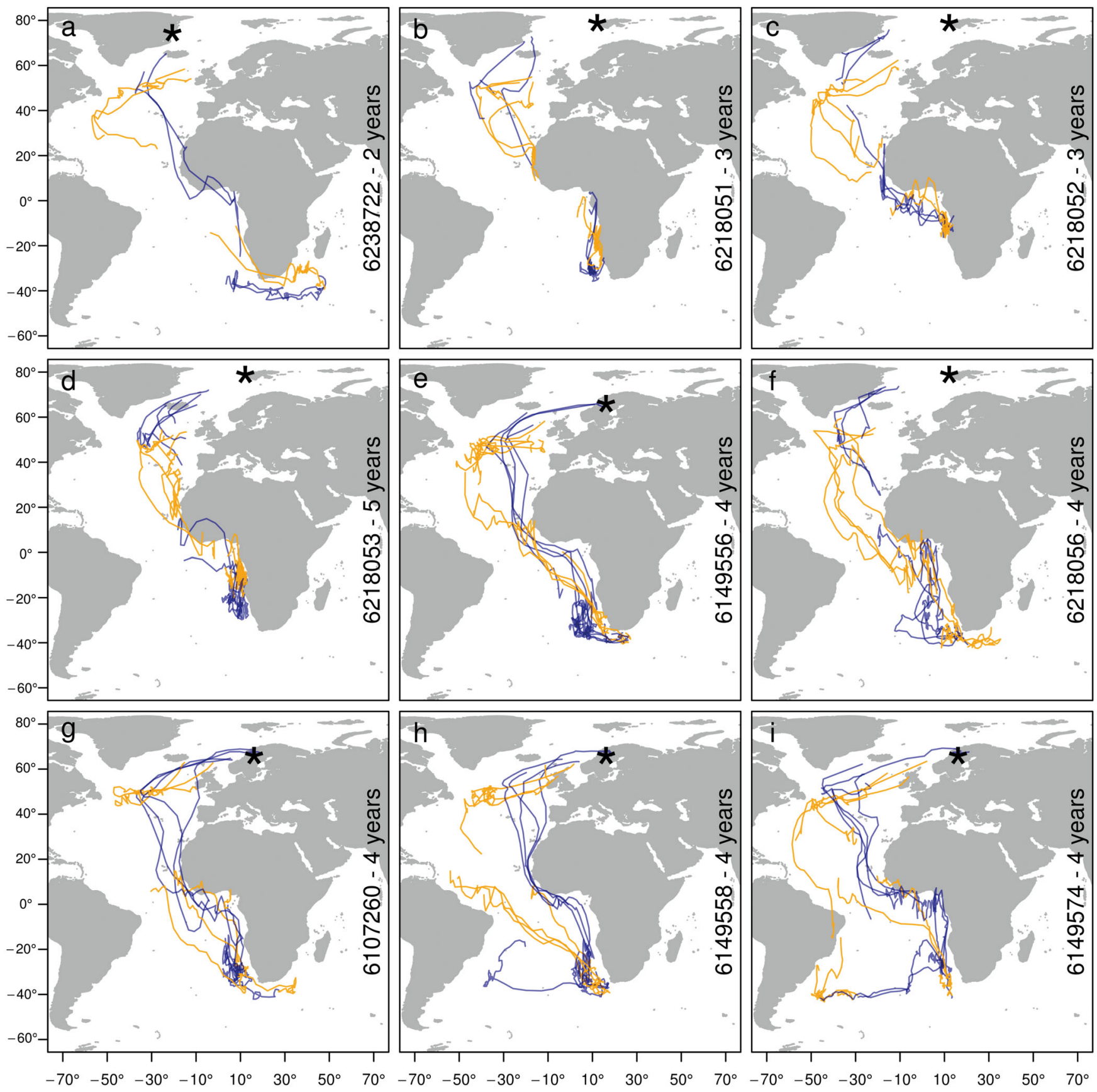

Fig. 2. Nine examples of geolocator tracks of individual long-tailed skuas Stercorarius longicaudus tracked over multiple years (blue: July-December, orange: January-June). Numbers on the right are ring numbers, cf. Fig. 6, and number of years tracked. Black stars indicate the breeding site of each individual. Examples include (a-e) individuals with high route consistency and (f-i) individuals with more flexibility in their recorded routes. The individual shown in (h) took a detour along the Falkland Current in one year, while the individual in (i) went to the Benguela Current in all 4 years, but switched mid-winter to the Falkland Current in its second and fourth year of tracking. Inaccuracy of geolocator position estimates is generally $\pm 185 \mathrm{~km}$, but is typically larger close to the equinoxes (Phillips et al. 2004)

Within-individual intertrack distances did not differ between the subspecies and therefore 'subspecies' was not included in the models $\left(\mathrm{p}_{\mathrm{MCMC}}=0.448\right)$. Within-individual intertrack distance was largest out- side staging area kernels during northbound (Fig. 4; $\mu=702 \mathrm{~km}, 95 \% \mathrm{CI}=500-1026 \mathrm{~km})$ and southbound migration $(\mu=689 \mathrm{~km}, 95 \% \mathrm{CI}=524-871 \mathrm{~km})$, which were not significantly different $\left(\mathrm{p}_{\mathrm{MCMC}}=0.944\right)$. 

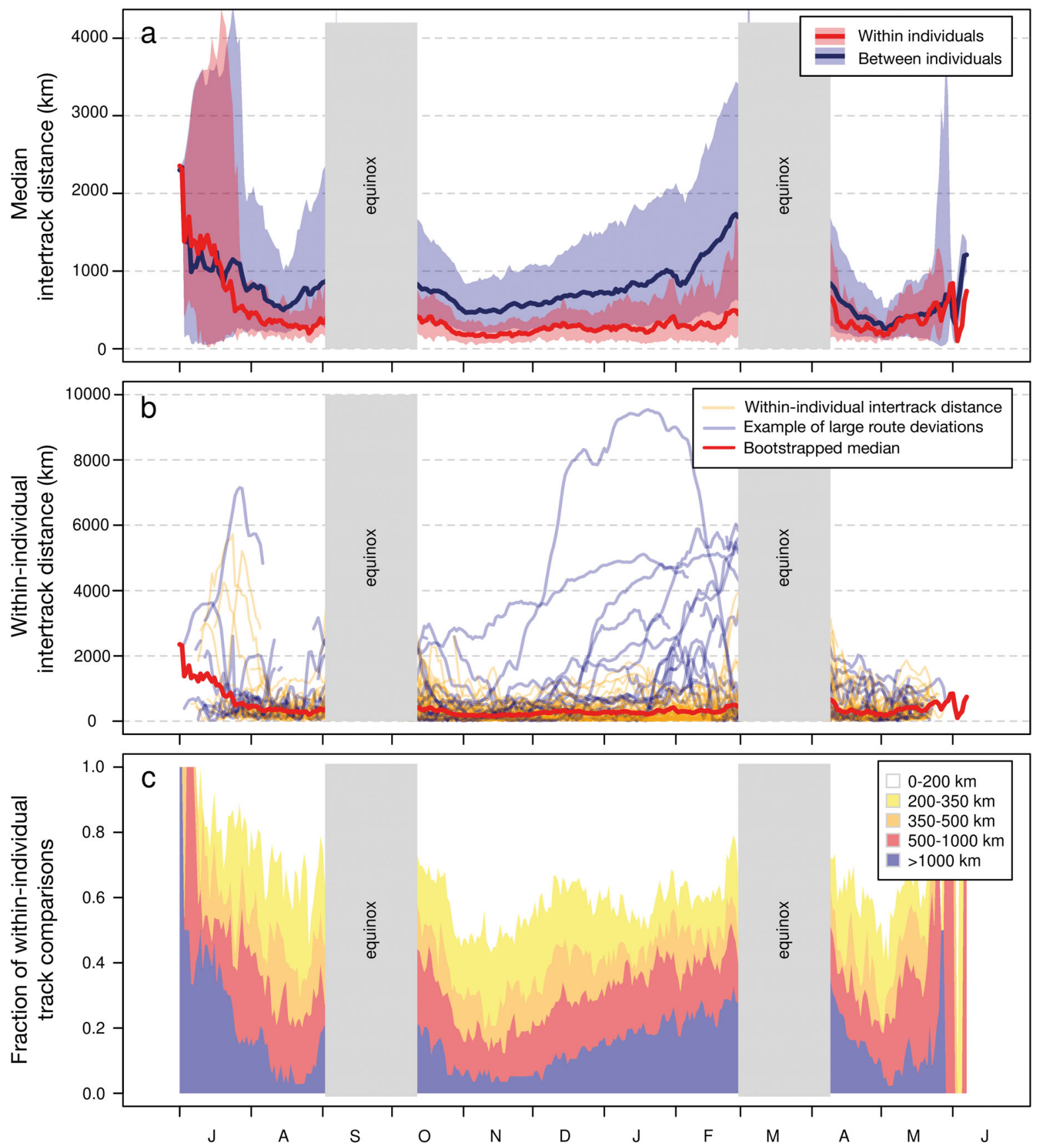

Fig. 3. Daily route consistency per month. (a) Distribution of bootstrapped median intertrack distances (red and blue) for comparisons within (red) and between (blue) individual long-tailed skuas Stercorarius longicaudus. Shaded areas represent $90 \%$ $\mathrm{CI}$ of bootstrapped median intertrack distances, including their overlap (darker red/blue). (b) Within-individual intertrack distances (orange), highlighting examples of large deviations from the previous year's track (blue). The red line shows the bootstrapped median within-individual intertrack distance also shown in panel (a). (c) Fraction of tracks with a certain range of intertrack distances. White represents high route consistency $(<200 \mathrm{~km})$; purple reflects large route deviations $(>1000 \mathrm{~km})$

Within-individual intertrack distances outside staging area kernels were larger than within-individual distances within the staging area kernels (Fig. $4 ; \mathrm{p}_{\mathrm{MCMC}}<$ 0.05), except for the comparison between southbound migration and the North Atlantic staging area in au- tumn $\left(\mathrm{p}_{\mathrm{MCMC}}=0.084\right)$. Considering staging kernels, intertrack distances were larger in the North Atlantic staging area during autumn $(\mu=414 \mathrm{~km}, 95 \% \mathrm{CI}=$ 299-610 km) than in the staging areas south of $25^{\circ} \mathrm{N}$ during early winter $(\mu=278 \mathrm{~km}, \mathrm{CI}=160-323 \mathrm{~km}$, 


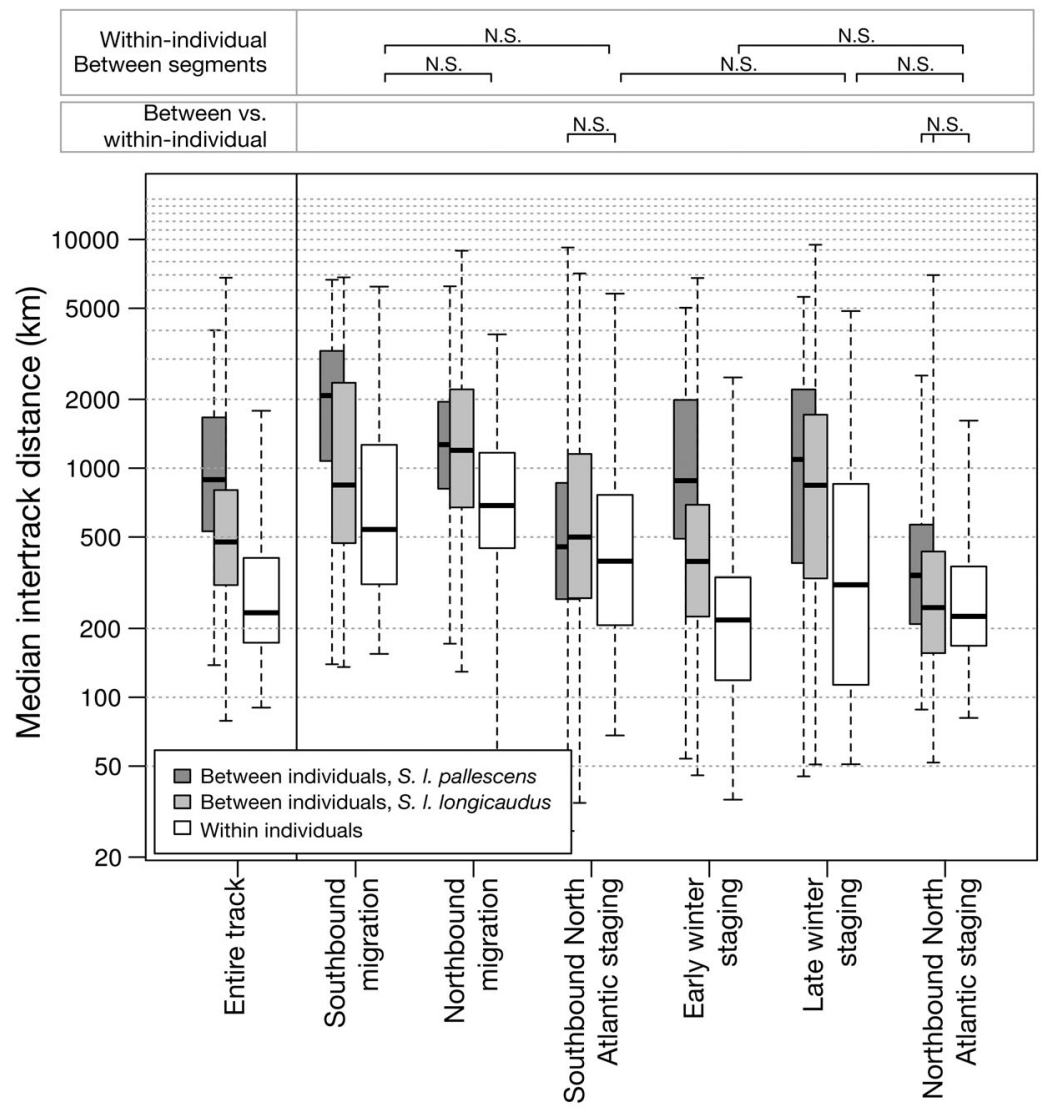

Fig. 4. Median intertrack distance within individual long-tailed skuas Stercorarius longicaudus, and between individuals of each subspecies (light/dark grey), calculated for the entire track comparison and for 6 segments (see 'Materials and methods: Consistency in movement patterns'). Note the log scale of the $y$-axis. Bold horizontal lines represent medians, boxes encompass $50 \%$ of the values, and whiskers extend to the most extreme values. Above the figure, only non-significant (N.S.) comparisons are indicated; all other comparisons are significant $\left(\mathrm{p}_{\mathrm{MCMC}}<0.05\right)$

$\left.\mathrm{p}_{\mathrm{MCMC}}<0.001\right)$ and in the North Atlantic staging area during northbound migration $(\mu=255 \mathrm{~km}, 95 \% \mathrm{CI}=$ $\left.175-362 \mathrm{~km}, \mathrm{p}_{\mathrm{MCMC}}=0.018\right)$, but not different in the staging areas south of $25^{\circ} \mathrm{N}$ in late winter $(\mu=347 \mathrm{~km}$, $\left.95 \% \mathrm{CI}=248-479 \mathrm{~km}, \mathrm{p}_{\mathrm{MCMC}}=0.324\right)$. Intertrack distances in staging areas were smaller during early winter than during late winter $\left(\mathrm{p}_{\mathrm{MCMC}}=0.016\right)$. In Fig. 3a, intertrack distances plotted per day over the entire year (irrespective of location) show that withinindividual intertrack distances are smallest and individuals thus especially consistent in space and time in August (medians range from 200 to $340 \mathrm{~km}$ ) and late April/early May (when in the North Atlantic staging area; medians range from 170 to $270 \mathrm{~km}$ ), and in November (when in the winter quarters; medians range from 160 to $210 \mathrm{~km}$ ). In the months after November, an increasing number of individuals diverted from their previous year's route; for example in February, about $40 \%$ deviated more than $500 \mathrm{~km}$ and $20 \%$ more than $1000 \mathrm{~km}$. Within-individual intertrack distance did not differ between years (included as a factor).

Spatial patterns in between-individual intertrack distance reflect largely where individuals aggregate at staging areas, for example in the central North Atlantic and in the Benguela Current, and where migration routes converge, such as for example in the East Atlantic during autumn migration (Fig. 5). In July to December, median intertrack distance was smaller within than between individuals in $77 \%$ of the grid cells, with some exceptions scattered mainly in the East Atlantic and west of the Benguela Current. Within-individual intertrack distances in this period were generally smaller than $500 \mathrm{~km}$ in the North Atlantic staging area, in the Benguela and Agulhas Currents, but also in between. Outside these areas, individuals showed lower route consistency. In January to June, $85 \%$ of the grid cells had lower within- than between-individual median intertrack distance. Uninterrupted areas of within-individual intertrack distances below $500 \mathrm{~km}$ were apparent again in the same main staging areas (albeit somewhat more restricted). With a few exceptions, intertrack distances were larger outside these areas, in particular between 0 and $40^{\circ} \mathrm{N}$.

Of those individuals with at least 3 yr of data (thus having 2 or more sets of intertrack distances), many repeatedly showed intertrack distances around 300 km (Fig. 6). However, several individuals showed small intertrack distances (high consistency) between 1 or 2 pairs of years and large intertrack distances (flexibility) between other set(s) of years. Thereby, within-individual variance of overall median intertrack distances was inflated, causing low ICC values $(r=0.286,95 \% C I=0.048-0.545)$. The same was found for the parts outside the staging kernels (southbound migration: $\mathrm{r}=0.041,95 \% \mathrm{CI}=0.010-$ 0.209 ; northbound migration: $\mathrm{r}=0.248,95 \% \mathrm{CI}=$ $0.029-0.491$ ) and within the staging kernels (southbound, North Atlantic staging area: $\mathrm{r}=0.073,95 \%$ $\mathrm{CI}=0.011-0.318$, early winter/south: $\mathrm{r}=0.225,95 \%$ $\mathrm{CI}=0.025-0.508 ;$ late winter/south: $\mathrm{r}=0.178,95 \%$ $\mathrm{CI}=0.011-0.430 ;$ spring/north: $\mathrm{r}=0.205,95 \% \mathrm{CI}=$ $0.025-0.427)$. 

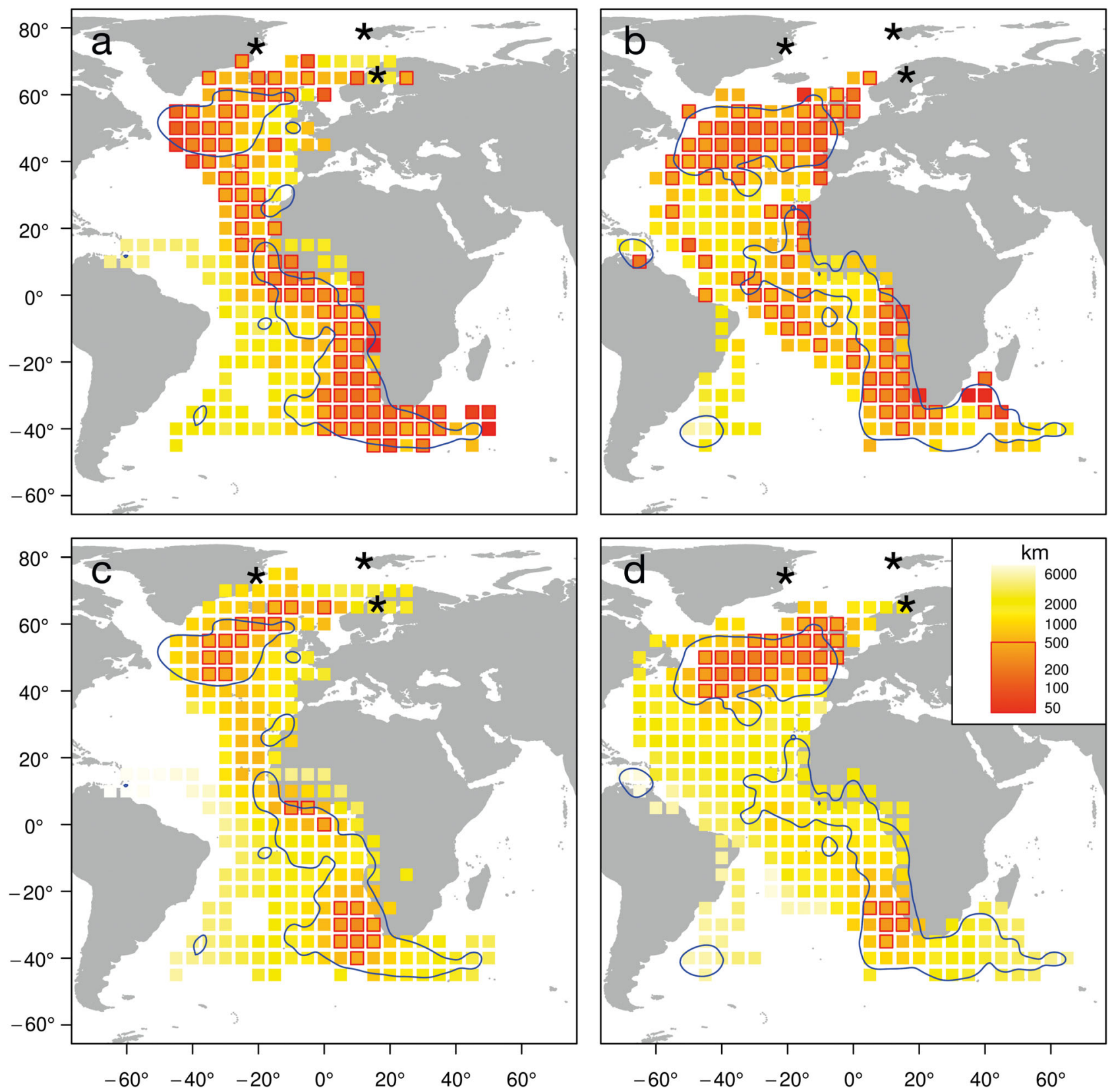

Fig. 5. Median intertrack distance $(\mathrm{a}, \mathrm{b})$ within individuals and $(\mathrm{c}, \mathrm{d})$ between individuals for $(\mathrm{a}, \mathrm{c})$ July-December and $(\mathrm{b}, \mathrm{d})$ January-June of long-tailed skuas Stercorarius longicaudus. Emphasis is put on grid cells $\left(5^{\circ}\right.$ latitude $\times 5^{\circ}$ longitude) with median intertrack distance of less than $500 \mathrm{~km}$ by red outlines. Black stars indicate the breeding locations and blue outlined polygons are $95 \%$ utilization distribution kernels (see Fig. 1). High route consistency is especially achieved in southbound migration both within and outside staging area kernels

\section{DISCUSSION}

We studied consistency of movement patterns at large to meso-scales outside the breeding season in a long-distance migratory seabird, the long-tailed skua Stercorarius longicaudus, and generally found large between-individual differences and relatively small within-individual variation. As expected, individuals were faithful to main staging areas in their southbound and northbound migration (off Newfoundland in the central North Atlantic) and winter destination (the Benguela Current off Namibia and South Africa), where they generally followed their previous year's route within about 200 to $300 \mathrm{~km}$, while being more 

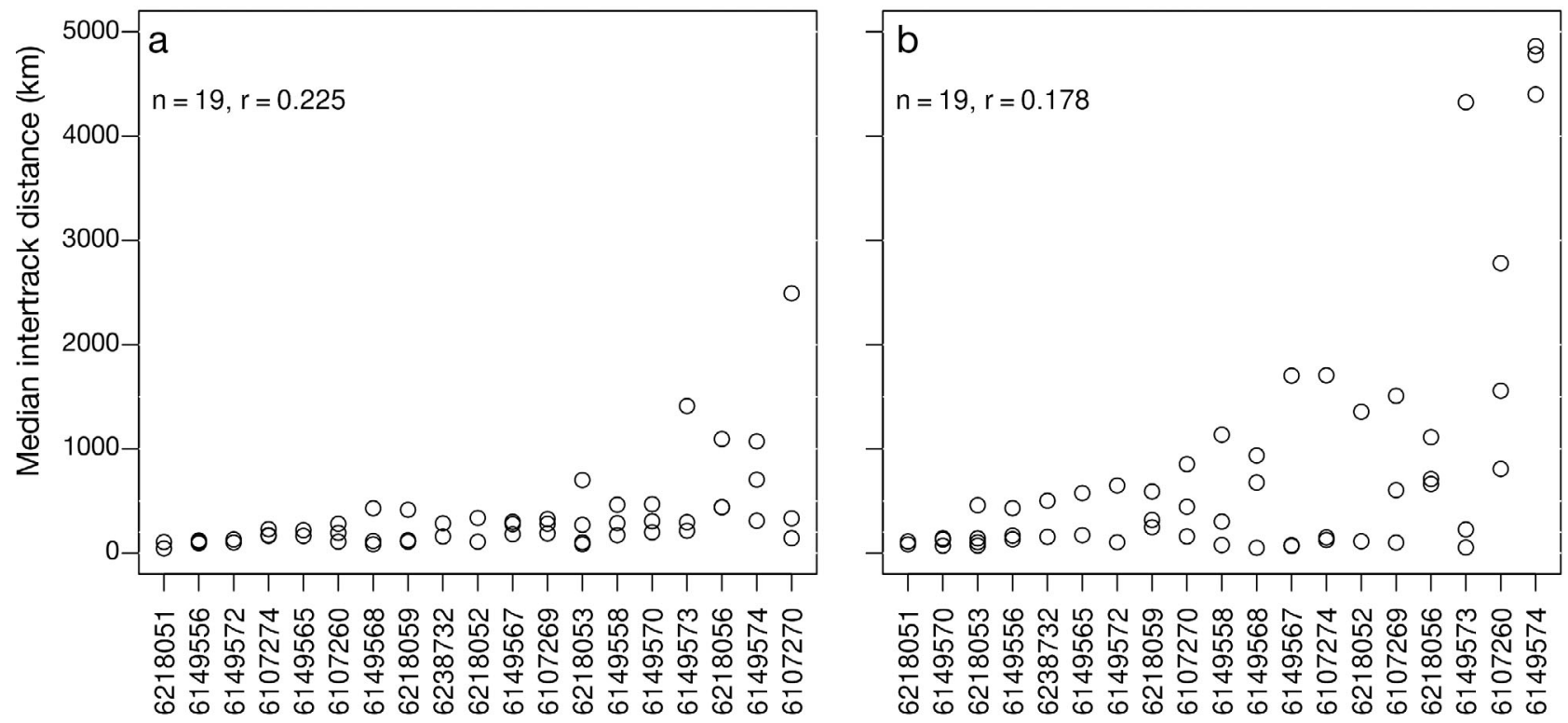

Fig. 6. Within-individual median intertrack distance in staging areas south of $25^{\circ} \mathrm{N}$ in (a) early winter and (b) late winter for individual long-tailed skuas Stercorarius longicaudus with at least 3 tracks, thus at least 2 sets of intertrack distances ( $x$-axis labels are individual ring numbers). Most individuals stayed within $500 \mathrm{~km}$ of their previous year's route in early winter. Particularly in late winter, some individuals showed large deviations in some years, but not in others. Individual 6149574 (far right; also see Fig. 2i) switched each year in late winter between 2 distinct strategies

flexible during southbound and northbound migration when crossing large areas with low productivity. Surprisingly, over the course of the winter, a minor but increasing part of the individuals started to deviate from their previous year's route. This shows an intriguing combination of general site fidelity and flexibility in subsequent winter movements.

High winter area fidelity has been shown in several seabird species from several families, using both GPS and light-based tracking devices (Phillips et al. 2005, Guilford et al. 2011, Muller et al. 2013, Fifield et al. 2014, McFarlane Tranquilla et al. 2014, Yamamoto et al. 2014). With generally high route consistency within staging areas throughout the winter months, long-tailed skuas fit to this pattern, although their movements are often not restricted to a single, welldefined area (i.e. strategy of itinerancy). The generally high route consistency indicates that, despite a strategy of itinerancy, similar itineraries are followed from one year to the next; thus, although individuals use different staging sites throughout the winter, they use the same staging sites in different years. These staging sites are well-known for their high productivity: the Benguela Current system, offshore Angola, the Gulf of Guinea, the Canary Current and the recently discovered hotspot for seabirds in the central North Atlantic (Longhurst 2006, Chavez \& Messié 2009, Stenhouse et al. 2012, Grecian et al.
2016). This is in line with our expectation that area fidelity is favoured when individuals target areas with predictably high productivity.

However, from late December, an increasing number of individuals deviated from the previous year's routes (Figs. $3 \& 6$ ). Much of this variation was due to differences in timing (see Fig. A1 and the Supplement), but even when controlling for this, ca. $20 \%$ of the tracks deviated more than $1000 \mathrm{~km}$ from the previous route in January (Fig. 3c). In extreme cases, the deviations included a transoceanic flight from the Benguela Current to the Falkland Current (ca. $5200 \mathrm{~km}$ ). The ability to switch wintering areas, sometimes at huge spatial scales, has been reported for a small number of seabird species (e.g. up to $7000 \mathrm{~km}$ in Cory's shearwater Calonectris borealis and $1300 \mathrm{~km}$ in streaked shearwater C. leucomelas; Dias et al. 2011, Yamamoto et al. 2014). One of the long-tailed skuas repeated the transoceanic switch even twice (in its second and fourth year of tracking; Figs. 2i \& 6) using similar routes and destination, indicating this leap was not just an accidental displacement by severe weather conditions, but likely based on previous experience. In both years, it made the shift after arrival in its usual winter range, the Benguela Current. The same pattern was observed in other individuals, in which deviations increasingly occurred from late December onwards, i.e. after arrival at the 
wintering areas. This suggests that individual skuas check local conditions at a familiar wintering site before deciding where to go during the following months. In contrast, some Cory's shearwaters directly travelled to a different wintering area than in the previous year, apparently without knowing the conditions at either wintering site (Dias et al. 2011).

Based on individuals with 3 to $5 \mathrm{yr}$ of tracking data, we conclude that individuals do not show the same degree of consistency between each set of subsequent years. Instead, individuals with dissimilar tracks between 2 years could have very similar tracks between other years (Fig. 6). This was already hinted at by Dias et al. (2011), who suggested that 'each individual may have one (or maybe several) 'preferred' migratory strategies (in terms of route and wintering site), but maintains the capacity to choose alternatives.' We can now confirm the intriguing idea of co-occurrence of site fidelity and site-switching within the same individual. In conjunction with the increase in route deviations after arrival at the wintering grounds, this likely indicates that deviations from earlier routes represent individuals' rapid responses to local conditions, for example, weather or foraging conditions (including competition) when arriving in the main wintering area.

What determines whether individuals are faithful to their wintering site or shift over small or large distances? While possibly modulated or constrained by intrinsic factors (genetic background, sex, experience, fat reserves), high variation in individual movement patterns likely results from declining availability, increased patchiness and decreased predictability of resources (Mueller \& Fagan 2008), or deteriorating weather conditions preventing efficient foraging. Dias et al. (2011) explored whether site switches of a small number of individuals could be explained by sex, age or reproductive success, or by changes in sea surface temperature and chlorophyll $a$, but found no clear links. Also, what exactly caused the movement deviations observed in long-tailed skuas in this study remains unclear. At-sea foraging behaviour of long-tailed skuas is poorly known, but most authors agree that they probably mostly feed by themselves (e.g. by surface pecking), only rarely kleptoparasitizing other seabirds, as is common in other skua species (Lambert 1980, Cramp \& Simmons 1983, Veit 1985, Wiley \& Lee 1998). As skuas are unable to dive deep, long-tailed skuas likely depend on mechanisms bringing zooplankton or fish at or very close to the surface. Many individuals aggregated in early winter in the southern Benguela Current. Here, edges of Agulhas rings (bodies of warm water 'leaking' from the Agulhas Retroflection) provide feeding opportunities for seabirds (Camphuysen \& van der Meer 2001, Camphuysen 2007), possibly including long-tailed skuas (cf. Ryan 1989). Whereas the occurrence of Agulhas rings within this large area seems predictable, they provide localized, slowly moving foraging areas, resulting in irregular patterns in inter-annual variation of ocean productivity (Chavez \& Messié 2009). In addition, sea surface temperature increases and primary productivity of the western part of the Benguela declines during winter (Hardman-Mountford et al. 2003, Longhurst 2006, O'Malley 2016). The skuas seem to respond to this by moving south- or eastwards within the Benguela, into the Agulhas or Angola Current, or to the Canary Current. Particularly these late-winter movements are consistent between most, but differ between some years and cause the observed increase in withinindividual intertrack distance from mid-winter onwards. While the onset of these movements may be related to the decrease in productivity, it is unclear what determines the (variation in) flexibility in subsequent destinations. One might argue that flexibility in late-winter movements is promoted by a lower predictability of resources in late winter. Whether this is really the case in our long-tailed skua example is questionable; targeted areas include both areas where they may use wind-driven upwelling areas along shelf-edges (off Angola and Namibia) and areas with eddies and thermal fronts (Agulhas Retroflection) (Ryan 1989), and such habitats do not seem to be notably less predictable in feeding conditions than, for example, the Benguela Current during early winter. Future studies should aim to link positional data with (ephemeral) oceanographic features (Tew Kai et al. 2009, Scales et al. 2014), backed up by field studies of at-sea feeding behaviour and diet. Examining at what conditions individual movement patterns start to deviate offers a promising opportunity to study movement decisions of seabirds.

In line with our expectations, long-tailed skuas showed lower consistency in migration route than in staging area itineraries. Like in many seabird species, migratory routes of long-tailed skuas are closely linked to large-scale oceanic wind patterns. They followed routes that provide tail- or sidewinds, except in the second half of southbound migration when using a narrow corridor hugging the contours of western Africa - against the prevailing wind but avoiding an area with stronger headwinds in the central South Atlantic. The same pattern is shown by Sabine's gulls Xema sabini and part of the Arctic terns Sterna paradisaea originating from the North 
Atlantic (Egevang et al. 2010, Stenhouse et al. 2012), but dissimilar to most Cory's shearwaters which take a westerly roundtrip offering more profitable winds (Felicísimo et al. 2008), a route taken by only a small number of the skuas in this study. Northbound migration towards the North Atlantic staging area occurred over a much broader front, in particular north of the equator, where birds likely experienced easterly winds over a large area. Despite this difference in longitudinal width of the south- and northbound migration, individuals showed a similar degree of consistency, albeit with large variation, generally staying within 300 and $1300 \mathrm{~km}$ of their previous year's route. High consistency was observed in particular after departure from the Benguela to the northwest, while more flexibility was shown in the North Atlantic south of the North Atlantic stopover. Higher consistency in northbound than in southbound migration route was also observed in the much shorter migration of streaked shearwaters in the western Pacific (Yamamoto et al. 2014).

Error of position estimates from light-based geolocation using the threshold method (Ekstrom 2004) are typically some $100 \mathrm{~s}$ of $\mathrm{km}$, which precludes us from any conclusions regarding consistency at smaller scales. Inaccuracy of latitude estimates are largest in proximity to the equinoxes (Phillips et al. 2004, Lisovski et al. 2012) and could lead to noise in derived measures. Indeed, Fig. 3a shows increased variation in median intertrack distances just before and after each equinox, but we do not exclude the possibility of an effect of data gaps around equinoxes. Nevertheless, 2 arguments suggest that the route consistencies as presented here are conservative and therefore our conclusions robust. First, considering that intertrack distances of 2 identical routes would reflect the combined error of the position estimates of both tracks, most within-individual intertrack distances are remarkably close to the typical error of $\pm 185 \mathrm{~km}$ of single-position estimates (Phillips et al. 2004). Second, intertrack distances were calculated as point-to-point measurements. Measuring the distance from each position in a focal track to the line between 2 closest positions in the comparison track would lead to even smaller distances, in particular if 2 positions of the comparison track are far apart (e.g. when the bird was migrating).

This study highlights that long-tailed skuas show consistency in non-breeding movements, but, at the same time, a fair amount of flexibility during specific parts of the annual cycle, in particular the late winter period. Variation in itineraries between and within individuals suggests that these birds have the ability to adjust to environmental change. However, as we have a poor understanding about how individual migration patterns arise in the first place, specifically the relative roles of genetics and learning during the ontogeny of individual patterns, and, in addition, to what extent individual migration patterns change over an individual's lifetime (reversible state effects; Senner et al. 2015), it remains unclear how flexible long-tailed skuas really are, and thus how quickly they can respond to environmental change. That an individual skua followed 2 distinct itineraries that were both repeated in later years (Fig. 2i), strongly suggests extensive spatial memory. This spatial memory may have its origin in explorative movements during early life (Pulido 2007, Guilford et al. 2011, Senner et al. 2015), which would enable longtailed skuas to respond to changes in the distribution of favourable areas relatively quickly, assuming that explorative movements allow for discovery of novel areas. Crucially, the genetic background, as well as the occurrence and extent of exploration behaviour in the first years of life and subsequent life stages, need to be demonstrated for the far majority of seabirds (but see Kooyman et al. 1996, Weimerskirch et al. 2006, Péron \& Grémillet 2013), including longtailed skuas.

Acknowledgements. This study would not have been possible without the huge effort by field crews. Piet Admiraal, Christian Brinkman, Michiel Elderenbosch, Juan FernándezElipe, Vincent Hin, Johannes Hungar, Puala Machin and Tim van der Meer assisted in Ammarnäs. Elise Biersma, Nora Bjørnlid, Anette A. Fenstad, Heidi Kilen, Thomas Oudman and Elise Skottene helped in Svalbard. In Greenland, assistance was provided by Antoine Dervaux, Bernhard Frauenberger, Jerome Isambert, Anita Lang, Ines Leonhardt, Mark Nitze at Karupelv, Lars H. Hansen, Jannie Lindebjerg, Jesper Mosbacher, Maria R. Mylius, Palle S. Nielsen and Jeroen Reneerkens at Zackenberg, and Vladimir Gilg, Arne Hegemann, Emmanuelle Pouivé, Brigitte Sabard and Glenn Yannic at Hochstetter Forland. Martin Green and Åke Lindström (Lund University) helped with permits and logistics in Ammarnäs. Aarhus University is thanked for providing logistics at Zackenberg. James Fox (Migrate Technology) and Glen Fowler (Biotrack) produced quality geolocators, provided advice and downloaded data from failed loggers. This study was partially financed by the Netherlands Organisation for Scientific Research (project number 866.13.005), the FRAM - High North Research Centre for Climate and the Environment, Research Council of Norway (Arctic Field Grant), Aage V. Jensen Charity Foundation, the French Polar Institute (Institut Polaire Français Emile Victor-IPEVprogramm 1036 'Interactions'), the Groupe de Recherche en Ecologie Arctique and supported by the LUVRE project (www.luvre.org). We thank Judy Shamoun-Baranes, an anonymous reviewer, and the editor for their helpful comments. 


\section{LITERATURE CITED}

Alerstam T (2006) Conflicting evidence about long-distance animal navigation. Science 313:791-794

Calenge $C$ (2011) Home range estimation in $R$ : the adehabitatHR package. Saint Benoist, Auffargis

Camphuysen CJ (2007) Where two oceans meet: distribution and offshore interactions of great-winged petrels Pterodroma macroptera and Leach's storm petrels Oceanodroma leucorhoa off southern Africa. J Ornithol 148: 333-346

Camphuysen CJ, van der Meer J (2001) Pelagic distribution, moult and (sub-)specific status of Cory's shearwaters Calonectris [d.] diomedea/borealis wintering off southern Africa. Mar Ornithol 29:89-96

Chavez FP, Messié M (2009) A comparison of Eastern Boundary upwelling ecosystems. Prog Oceanogr 83:80-96

Cramp S, Simmons KEL (1983) Handbook of the birds of Europe, the Middle East and North Africa. The birds of the Western Palearctic, Vol III: waders to gulls. Oxford University Press, Oxford

* Dias MP, Granadeiro JP, Phillips RA, Alonso H, Catry P (2011) Breaking the routine: individual Cory's shearwaters shift winter destinations between hemispheres and across ocean basins. Proc R Soc B 278:1786-1793

Dias MP, Granadeiro JP, Catry P (2013) Individual variability in the migratory path and stopovers of a long-distance pelagic migrant. Anim Behav 86:359-364

* Dingemanse NJ, Wolf M (2013) Between-individual differences in behavioural plasticity within populations: causes and consequences. Anim Behav 85:1031-1039

Egevang C, Stenhouse IJ, Phillips RA, Petersen A, Fox JW, Silk JRD (2010) Tracking of Arctic terns Sterna paradisaea reveals longest animal migration. Proc Natl Acad Sci USA 107:2078-2081

Ekstrom PA (2004) An advance in geolocation by light. Mem Natl Inst Polar Res Spec Issue 58:210-226

*Felicísimo ÁM, Muñoz J, González-Solis J (2008) Ocean surface winds drive dynamics of transoceanic aerial movements. PLOS ONE 3:e2928

Fifield DA, Montevecchi WA, Garthe S, Robertson GJ, Kubetzki U, Rail JF (2014) Migratory tactics and wintering areas of northern gannets (Morus bassanus) breeding in North America. Ornithol Monogr 79:1-63

Fijn RC, Hiemstra D, Phillips RA, van der Winden J (2013) Arctic terns Sterna paradisaea from the Netherlands migrate record distances across three oceans to Wilkes Land, East Antarctica. Ardea 101:3-12

Fridolfsson AK, Ellegren H (1999) A simple and universal method for molecular sexing of birds. J Avian Biol 30: 116-121

Gilg O, Moe B, Hanssen SA, Schmidt NM and others (2013) Trans-equatorial migration routes, staging sites and wintering areas of a high-Arctic avian predator: the longtailed skua (Stercorarius longicaudus). PLOS ONE 8: e64614

*Grecian WJ, Witt MJ, Attrill MJ, Bearhop S and others (2016) Seabird diversity hotspot linked to ocean productivity in the Canary Current Large Marine Ecosystem. Biol Lett 12:20160024

* Guilford T, Freeman R, Boyle D, Dean B, Kirk H, Phillips R, Perrins C (2011) A dispersive migration in the Atlantic puffin and its implications for migratory navigation. PLOS ONE 6:e21336

*Hadfield JD (2010) MCMC methods for multi-response gen- eralized linear mixed models: the MCMCglmm R package. J Stat Softw 33:1-22

*Hardman-Mountford NJ, Richardson AJ, Agenbag JJ, Hagen E, Nykjaer L, Shillington FA, Villacastin C (2003) Ocean climate of the South East Atlantic observed from satellite data and wind models. Prog Oceanogr 59: $181-221$

* Hedd A, Montevecchi WA, Otley H, Phillips RA, Fifield DA (2012) Trans-equatorial migration and habitat use by sooty shearwaters Puffinus griseus from the South Atlantic during the nonbreeding season. Mar Ecol Prog Ser 449:277-290

Kooyman G, Kooyman TG, Horning M, Kooyman CA (1996) Penguin dispersal after fledging. Nature 383:397

Lambert K (1980) Ein Überwinterungsgebiet der Falkenraubmöwe, Stercorarius longicaudus Vieill. 1819, vor Südwestund Südafrika entdeckt. Beitr Vogelkd 26:199-212

Lisovski S, Hahn S (2012) GeoLight_- processing and analysing light-based geolocator data in R. Methods Ecol Evol 3:1055-1059

Lisovski S, Hewson CM, Klaassen RHG, Korner-Nievergelt F, Kristensen MW, Hahn S (2012) Geolocation by light: accuracy and precision affected by environmental factors. Methods Ecol Evol 3:603-612

Longhurst AR (2006) Ecological geography of the sea, 2nd edn. Academic Press, San Diego, CA

Manning TH (1964) Geographical and sexual variation in the long-tailed jaeger Stercorarius longicaudus Vieillot. Biol Pap Univ Alsk 7:1-16

McFarlane Tranquilla LA, Montevecchi WA, Fifield DA, Hedd A, Gaston AJ, Robertson GJ, Phillips RA (2014) Individual winter movement strategies in two species of murre (Uria spp.) in the Northwest Atlantic. PLOS ONE 9:e90583

Moreau RE (1972) The Palearctic-African bird migration system. Academic Press, London

* Mueller T, Fagan WF (2008) Search and navigation in dynamic environments - from individual behaviours to population distributions. Oikos 117:654-664

Muller M, Massa B, Dell Omo G (2013) Individual consistency and sex differences in migration strategies of Scopolis shearwaters (Calonectris diomedea) despite systematic year differences. Curr Zool 60:1-17

Nakagawa S, Schielzeth H (2010) Repeatability for Gaussian and non-Gaussian data: a practical guide for biologists. Biol Rev Camb Philos Soc 85:935-956

Newton I (2010) The migration ecology of birds. Academic Press, London

O'Malley R (2016) Ocean productivity. www.science.oregon state.edu/ocean.productivity/

\% Orben RA, Paredes R, Roby DD, Irons DB, Shaffer SA (2015) Wintering North Pacific black-legged kittiwakes balance spatial flexibility and consistency. Mov Ecol 3:36

*Péron C, Grémillet D (2013) Tracking through life stages: adult, immature and juvenile autumn migration in a long-lived seabird. PLOS ONE 8:e72713

*Phillips RA, Silk JRD, Croxall JP, Afanasyev V, Briggs DR (2004) Accuracy of geolocation estimates for flying seabirds. Mar Ecol Prog Ser 266:265-272

* Phillips RA, Silk JRD, Croxall JP, Afanasyev V, Bennett J (2005) Summer distribution and migration of nonbreeding albatrosses: individual consistencies and implications for conservation. Ecology 86:2386-2396

Pulido F (2007) The genetics and evolution of avian migration. Biomed Sci 57:165-174

R Core Team (2015) R: a language and environment for sta- 
tistical computing. R Foundation for Statistical Computing, Vienna

Ryan PG (1989) The distribution and abundance of longtailed skuas off southern Africa. Ostrich 60:89-90

Scales KL, Miller PI, Embling CB, Ingram SN, Pirotta E, Votier SC (2014) Mesoscale fronts as foraging habitats: composite front mapping reveals oceanographic drivers of habitat use for a pelagic seabird. J R Soc Interface 11:20140679

Schielzeth H, Nakagawa S (2013) rptR: repeatability for Gaussian and non-Gaussian data. R package version 0.6. 405/r52. https://cran.r-project.org/web/packages/rptR/

Senner NR, Conklin JR, Piersma T (2015) An ontogenetic perspective on individual differences. Proc R Soc B 282: 20151050

Sittler B, Aebischer A, Gilg O (2011) Post-breeding migration of four long-tailed skuas (Stercorarius longicaudus) from North and East Greenland to West Africa. J Ornithol 152:375-381

Stenhouse IJ, Egevang C, Phillips RA (2012) Trans-equatorial migration, staging sites and wintering area of Sabine's gulls Larus sabini in the Atlantic Ocean. Ibis 154:42-51

Tew Kai E, Rossi V, Sudre J, Weimerskirch H and others (2009) Top marine predators track Lagrangian coherent structures. Proc Natl Acad Sci USA 106:8245-8250

Trierweiler C, Mullié WC, Drent RH, Exo KM and others (2013) A Palaearctic migratory raptor species tracks shifting prey availability within its wintering range in the Sahel. J Anim Ecol 82:107-120 van der Winden J, Fijn RC, van Horssen PW, GerristenDavidse D, Piersma T (2014) Idiosyncratic migrations of black terns (Chlidonias niger): diversity in routes and stopovers. Waterbirds 37:162-174

*van Noordwijk AJ, Pulido F, Helm B, Coppack T and others (2006) A framework for the study of genetic variation in migratory behaviour. J Ornithol 147:221-233

Vardanis Y, Klaassen RHG, Strandberg R, Alerstam T (2011) Individuality in bird migration: routes and timing. Biol Lett 7:502-505

Vardanis Y, Nilsson JÅ, Klaassen RHG, Strandberg R, Alerstam $T$ (2016) Consistency in long-distance bird migration: contrasting patterns in time and space for two raptors. Anim Behav 113:177-187

Veit RR (1985) Long-tailed jaegers wintering along the Falkland Current. Am Birds 39:873-878

*Weimerskirch H (2007) Are seabirds foraging for unpredictable resources? Deep-Sea Res II 54:211-223

Weimerskirch H, Åkesson S, Pinaud D (2006) Postnatal dispersal of wandering albatrosses Diomedea exulans: implications for the conservation of the species. J Avian Biol 37:23-28

Wiley RH, Lee DS (1998) Long-tailed jaeger (Stercorarius longicaudus). The birds of North America, No. 365. Academy of Natural Sciences, Philadelphia, PA

* Yamamoto T, Takahashi A, Sato K, Oka N, Yamamoto M, Trathan PN (2014) Individual consistency in migratory behaviour of a pelagic seabird. Behaviour 151:683-701

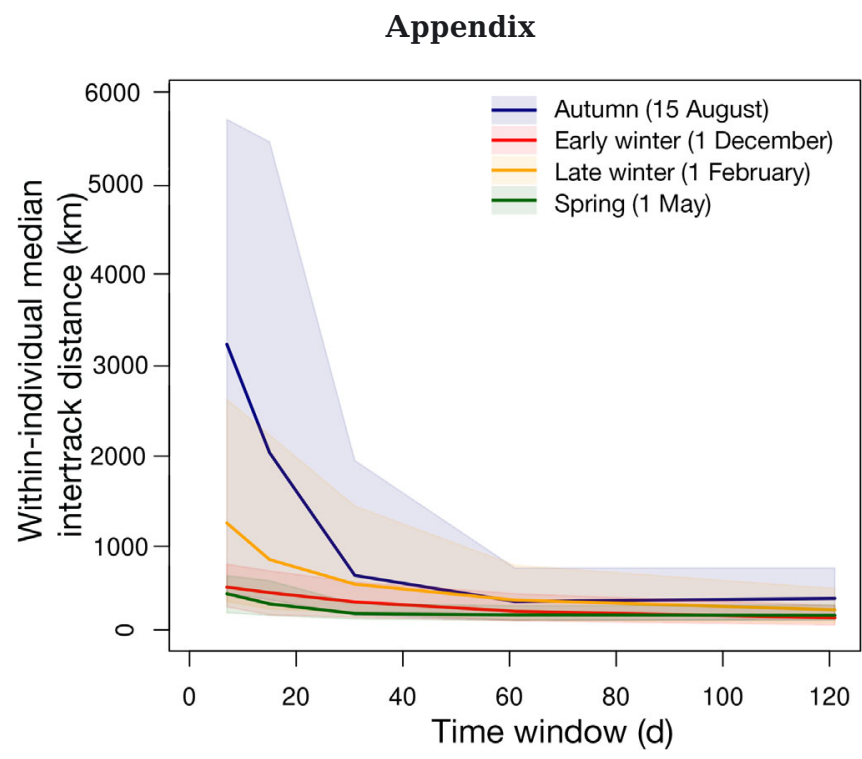

Fig. A1. Effect of widening the time window (from 7 to $121 \mathrm{~d}$ ) on median within-individual intertrack distances of longtailed skuas Stercorarius longicaudus on 4 example dates. Shaded areas represent $90 \%$ CI of bootstrapped medians. Intertrack distances using a time window of $61 \mathrm{~d}$ were selected for further analyses

Editorial responsibility: Jacob González-Solís (Guest Editor), Barcelona, Spain
Submitted: May 2, 2016; Accepted: December 12, 2016 Proofs received from author(s): February 3, 2017 